\title{
Assessment of the nutritive value of fermented cassava root leaf meal as a reflect on blood profile of ducks
}

${ }^{1}$ Olayemi, W. A., ${ }^{1}$ Rabiu, L. A., ${ }^{2}$ Oso, A. O., ${ }^{2}$ Akapo, O. A. and ${ }^{2}$ Bamgbose, A. M. ${ }^{\prime}$ Department of Agricultural Technology, Yaba college of Technology, Lagos

'Department of Animal Nutrition, Federal University of Agriculture, Abeokuta

Abstract

Corresponding author: w_olayemi@yahoo.co.uk,+2348023671812

\begin{abstract}
Due to scarcity and high cost of conventional feedstuffs, there is a renewed interest in the use of non-conventional cheap and easily available feedstuffs on ducks feeding. This study was conducted to evaluate health status of ducks fed fermented cassava root-leaf meal blend as a replacement for maize. One hundred and fifty, one day-old unsexed Mallard ducklings were used for the experiment. Ducklings were randomly distributed into 5 groups of 30 ducklings per treatment. Each treatment was further subdivided into 3 replicates with 10 ducklings per replicate in a completely randomized design (CRD). The study is made up of 5 dietary treatments consisting of the control (Treatment 1), fermented cassava root-leaf blend used to replace maize at 25\% (Treatment 2), 50\% (Treatment 3), 75\% (Treatment 4) and 100\% (Treatment 5) levels respectively. The packed cell volume (26.50-38.33\%) and haemoglobin (9.35-14.07g/dl) levels increased as Fermented cassava root-leaf meal (FCRLM) inclusion increased in the diet (0-75\%). Uric acid values decreased (5.30-4,27mg/dl) as well as cholesterol values $(91.70-56.70 \mathrm{mg} / \mathrm{dl})$ as level of $(F C R L M)$ increased in diet. The results obtained showed that FCRLM at (300:1000 ratio) of leaf to root could replace maize at 50\% inclusion level without any detrimental effects on health status of ducks.
\end{abstract}

Keywords: Ducks, cassava root- leaf meal, fermentation, haematology and serum

\section{Introduction}

Diet needed for survival of animals and humans due to its basic function in nutrition to supply adequate amount of needed amino acids must be properly addressed (Owosibo and Longe, 2007). Dietary components affect the blood profile of healthy birds (Iheukwumere and Herbert, 2012). It is often very difficult to assess the current health status of animals without detailed examination of blood (Amakiri et al., 2009). Examination of blood provides the opportunity to clinically investigate the presence of several metabolites and other constituents in the body and it plays a vital role in the physiological, nutritional and pathological status of the animal (Aderemi, 2004; Doyle and Williams, 2006). The haematological examination is among the methods which may contribute to the detection of some changes in health and physiological status, which may not be apparent during physical examination but which affects the fitness of the animal (Bamishaiye et al., 2009). They are good indicators of the physiological status of animals (Adenkola and Durutoye, 2004; Adenkola et al., 2008) and it changes are of value in assessing the response of animals to various physiological situations and disease conditions (Schalm et al., 1975). Evaluation and interpretation of the results obtained are dependent on the reference values for each animal species, in those regions under existing environmental conditions (Otto et al., 2000) which are used as reference point for comparing and interpretation of metabolic state or condition of animals (Babatunde et al., 1992). In Nigeria, due to the scarcity and high cost of conventional ingredients, there is a renewed interest in the use of non-conventional cheap and easily available ingredients in feeding birds. Cassava products have been in use for a long time as an energy source in place of cereal grains for livestock (Eruvbetine et 


\section{Assessment of the nutritive value of fermented cassava root leaf meal}

al., 2003) but limited by its high fibre content, low protein value and hydrocyanic acid which is deleterious to animal growth and development (Tewe and Iyayi, 1989; Panigrahi ,1996; Yeoh and Yruong, 1993). The inclusion of leaf meal in poultry nutrition serves as sources of proteins, vitamins, minerals and carotenoids. Fermentation technology has been used as a method of improving the nutritional value of cassava meal by reducing the antinutritional factors, high crude fibre content and enriching the protein content in livestock feeds (Aro et al., 2008; Oboh and Akindahunsi, 2003) This study was aimed at determining the level at which fermented cassava root leaf meal can replace maize as energy source in ducks' diets without detrimental effect on physiological, pathological and nutritional status of ducks.

\section{Materials and methods \\ Experimental site}

The project was carried out at the Teaching and Research farm of Yaba College of
Technology Epe Lagos State. It is situated at latitude $6.58^{\circ} \mathrm{N}$, Longitude $3.98^{\circ} \mathrm{E}$. It is $42 \mathrm{~m}$ above the sea level along the EpeIjebu Ode road. Epe lies in the low land rain forest, vegetation zone within the savannah agro ecological zones of south Nigeria (Google earth, 2015).

\section{Cassava root-leaf meal processing}

Fresh cassava root tubers (TMS30572) were harvested, washed and grated. The cassava leaves were harvested and chopped into smaller pieces using kitchen knife. A maize-soybean diet was formulated as control. Fresh grated cassava root and leaves were mixed at a ratio of $1 \mathrm{~kg}$ cassava root meal with $300 \mathrm{~g}$ cassava leaves, fermented for 5days under an air-tight environment, air dried (for 2-3 days) and used to replace maize at varying proportions in the basal diet. Products obtained at the expiration of the fermentation were analysed for proximate composition using standard methods (AOAC, 2002).

Table 1 : Proximate composition of fermented cassava root leaf meal blend at graded level

\begin{tabular}{llllll} 
Parameters \% & A & B & C & D & E \\
\hline Moisture & 29.18 & 30.22 & 34.08 & 30.04 & 39.51 \\
Crude protein & 6.12 & 7.40 & 8.82 & 9.30 & 9.76 \\
Crude Fat & 1.51 & 1.94 & 2.64 & 3.14 & 3.95 \\
Crude fibre & 6.75 & 5.35 & 3.27 & 3.79 & 3.84 \\
Total ash & 1.34 & 1.48 & 1.55 & 2.05 & 2.35 \\
NFE & 55.12 & 53.62 & 49.63 & 51.71 & 40.55 \\
\hline
\end{tabular}

*Average of three determinations.

\section{Experimental birds, management and design}

One hundred and fifty, one-day old unsexed Mallard ducklings was distributed randomly into 5 groups of 30 ducklings per treatment. Each treatment was further subdivided into 3 replicates with 10 ducklings per replicate in complete randomized design (CRD). The study is made up of 5 dietary treatments consisting of control (Treatment 1), fermented cassava root-leaf blend used to replace maize at $25 \%$ (Treatment 2), 50\%
(Treatment 3), 75\% (Treatment 4) and $100 \%$ (Treatment 5) levels, respectively. Diets were formulated to meet the NRC (1994) requirements. The ducklings were raised on deep litter in an open sided deep litter house. Feed were offered ad libtum. The study was conducted for a period of 6 weeks.

\section{Data collection}

\section{Measurement of haematological indices}

Blood samples meant for haematological indices analysis were collected from ducks at 42 days from 6 birds per treatment 


\section{Olayemi, Rabiu, Oso, Akapo and Bamgbose}

through wing vein using sterilized syringe. Blood $(2.5 \mathrm{~mL})$ was collected from each bird into vials containing ethytlene diamine tetra-acetic acid (EDTA) as anticoagulant and used for the following hematological determinations: packed cell volume (PCV), red blood cell count (RBC), haemoglobin concentration $(\mathrm{Hb})$, total white blood cell count (WBC), and percentage distribution of white blood cells (differential leukocyte count) using standard techniques (Schalms et al., 1975; Coles, 1986).

\section{Measurement of serum metabolites}

Blood samples were collected from ducks at 42 days from 6 birds per treatment through wing vein using sterilized syringe. $2.5 \mathrm{ml}$ blood was collected from each bird into vials without anticoagulants and were allowed to clot. The serum from the clotted blood samples were used to determine Total serum protein (TSP), Serum albumin (SA),
Serum globulin (SG), Serum uric acid (SUA), Serum creatinine (SC), Serum glucose (SG), Serum enzyme activity (ALT and AST). The total serum protein was determined according to the method of Colowick and Kaplan (1955), while serum albumin and globulin were determined using bromocresol purple method of Varley et al. (1980). Serum creatinine was determined using the principle of Jaffe reaction as described by Bousnes and Tauslay (1945) while the serum uric acid was determined by the kit (QuinicaClinica Spam) (Wooton, 1964). Serum glucose was determined colorimetrically using the method described by Braham and Trinder (1972). Serum cholesterol was determined by enzymatic end point method as described by Roeschlau et al. (1974) while serum enzyme activity was determined using the colorimetric method.

Table 2: percentage composition of the experimental diet (duck starter 0-21days)

\begin{tabular}{|c|c|c|c|c|c|}
\hline Ingredients & $\mathrm{T} 1$ & $\mathrm{~T} 2$ & T3 & T4 & T5 \\
\hline Maize & 54.00 & 40.50 & 27.00 & 13.50 & 0.00 \\
\hline Vegetable oil & 1.00 & 1.00 & 1.00 & 1.00 & 1.00 \\
\hline Soybean meal & 30.00 & 30.00 & 30.00 & 30.00 & 30.00 \\
\hline FCRLM & 0.00 & 13.50 & 27.00 & 40.00 & 54.00 \\
\hline Wheat offal & 6.00 & 6.00 & 6.00 & 6.00 & 6.00 \\
\hline Fish meal $(72 \%)$ & 3.00 & 3.00 & 3.00 & 3.00 & 3.00 \\
\hline Bone & 3.00 & 3.00 & 3.00 & 3.00 & 3.00 \\
\hline Limestone & 2.00 & 2.00 & 2.00 & 2.00 & 2.00 \\
\hline Lysine & 0.25 & 0.25 & 0.25 & 0.25 & 0.25 \\
\hline Methionine & 0.20 & 0.20 & 0.20 & 0.20 & 0.20 \\
\hline Salt & 0.25 & 0.25 & 0.25 & 0.25 & 0.25 \\
\hline Premix* & 0.30 & 0.30 & 0.30 & 0.30 & 0.30 \\
\hline Total & 100.00 & 100.00 & 100.00 & 100.00 & 100.00 \\
\hline FCRLM: & \multirow{2}{*}{\multicolumn{5}{|c|}{ fermented cassava root leaf meal }} \\
\hline Calculated analysis. & & & & & \\
\hline Crude protein $\%$ & 21.30 & 21.34 & 21.38 & 21.41 & 21.46 \\
\hline Crude fibre \% & 4.25 & 3.98 & 3.71 & 3.44 & 3.17 \\
\hline Calcium $\%$ & 1.19 & 1.19 & 1.19 & 1.19 & 1.19 \\
\hline Phosphorus \% & 0.65 & 0.65 & 0.65 & 0.65 & 0.65 \\
\hline Energy (Kcal/kg) & 2864 & 2827 & 2870 & 2913 & 2956 \\
\hline \multicolumn{6}{|c|}{$\begin{array}{l}\text { Starter premix: -Vit. A 8, 500,000 (iu), Vit D3 1,500,000 (iu), Vit. E 10,000(mg), Vit K3 1,500 (mg), Vit B1 1,600 (mg), } \\
\text { Vit. B2 4,000 (mg), Niacin 20,000 mg, Pantothenic acid 5,000mg, Vit. D6 1,500mg, Vit.B12 10mg, Folic acid 500mg, } \\
\text { Biotin H2 750mg, Chlorine ch loride 175,000mg,Cobalt 200mg, Copper 3,000mg, lodine 1,000mg, Iron 20,000mg, } \\
\text { Manganese 40,000(mg), Selenium 200mg, Zinc 30,000mg, Anti-oxidant 1,250mg.T1(0\% replacement level), T2 (25\% } \\
\text { replacement level), T3 (50\%replacement level),T4 (75\% replacement level), T5 (100\% replacement level). }\end{array}$} \\
\hline
\end{tabular}




\section{Assessment of the nutritive value of fermented cassava root leaf meal}

Table 3: Percentage composition of the experimental diet (Duck finisher $22-42$ days)

\begin{tabular}{llllll}
\hline Ingredients & $\mathrm{T} 1$ & $\mathrm{~T} 2$ & $\mathrm{~T} 3$ & $\mathrm{~T} 4$ & $\mathrm{~T}$ \\
\hline Maize & 48.00 & 36.00 & 24.00 & 12.00 & 0.00 \\
Vegetable oil & 2.00 & 2.00 & 2.00 & 2.00 & 2.00 \\
Soybean meal & 36.00 & 36.00 & 36.00 & 36.00 & 36.00 \\
FCRLM & 0.00 & 12.00 & 24.00 & 36.00 & 48.00 \\
Wheat offal & 7.00 & 7.00 & 7.00 & 7.00 & 7.00 \\
Bone & 3.00 & 3.00 & 3.00 & 3.00 & 3.00 \\
Limestone & 3.00 & 3.00 & 3.00 & 3.00 & 3.00 \\
Lysine & 0.25 & 0.25 & 0.25 & 0.25 & 0.25 \\
Methionine & 0.20 & 0.20 & 0.20 & 0.20 & 0.20 \\
Salt & 0.25 & 0.25 & 0.25 & 0.25 & 0.25 \\
Premix* & 0.30 & 0.30 & 0.30 & 0.30 & 0.30 \\
Total & 100.00 & 100.00 & 100.00 & 100.00 & 100.00 \\
FCRLM: & fermented cassava root leaf meal & & \\
Calculated analysis. & & & & \\
Crude protein \% & 21.42 & 21.45 & 21.49 & 21.52 & 21.57 \\
Crude fibre \% & 4.72 & 5.60 & 5.34 & 5.67 & 5.89 \\
Calcium\% & 1.19 & 1.19 & 1.19 & 1.19 & 1.19 \\
Phosphorus\% & 0.65 & 0.65 & 0.65 & 0.65 & 0.66 \\
Energy & 2657 & 2695 & 2733 & 2771 & 2809 \\
(Kcal/kg) & & & & & \\
Star & & & & & \\
\end{tabular}

Starter premix: -Vit. A 8, 500,000 (iu), Vit D3 1,500,000 (iu), Vit. E 10,000(mg), Vit K3 1,500 (mg), Vit B1 1,600 (mg), Vit. B2 4,000 (mg), Niacin 20,000 mg, Pantothenic acid 5,000mg, Vit. D6 1,500mg, Vit.B12 10mg, Folic acid 500mg, Biotin H2 750mg, Chlorine chloride 175,000mg,Cobalt 200mg, Copper 3,000mg, lodine 1,000mg, Iron 20,000mg, Manganese 40,000(mg), Selenium 200mg, Zinc 30,000mg, Anti-oxidant 1,250mg.T1(0\% replacement level), T2 (25\% replacement level), T3 (50\%replacement level), T4 (75\% replacement level), T5 (100\% replacement level).

Table 4: Haematological indices of ducks fed fermented cassava root-leaf meal as maize

\begin{tabular}{lllllll}
\multicolumn{1}{c}{ equivalent } & T1 & T2 & T3 & T4 & T5 & SEM \\
\hline Parameters & $26.50^{\mathrm{c}}$ & $32.00^{\mathrm{b}}$ & $38.00^{\mathrm{a}}$ & $38.33^{\mathrm{a}}$ & $32.00^{\mathrm{b}}$ & 1.21 \\
\hline Packed cell volume (\%) & $9.35^{\mathrm{b}}$ & $10.56^{\mathrm{b}}$ & $13.18^{\mathrm{a}}$ & $14.07^{\mathrm{a}}$ & $10.37^{\mathrm{b}}$ & 0.53 \\
Haemoglobin $(\mathrm{g} / \mathrm{dl})$ & $1.92^{\mathrm{d}}$ & $2.30 \mathrm{~b}^{\mathrm{c}}$ & $2.67^{\mathrm{a}}$ & $2.49^{\mathrm{ab}}$ & $2.17 \mathrm{c}$ & 0.07 \\
Red blood cell $\left(\mathrm{x} 10^{12} / 1\right)$ & $10.73^{\mathrm{b}}$ & $10.98^{\mathrm{b}}$ & $12.17^{\mathrm{a}}$ & $11.57^{\mathrm{ab}}$ & $11.07^{\mathrm{b}}$ & 0.17 \\
White blood cell $\left(\mathrm{Cumm}^{3}\right)$ & 36.33 & 39.67 & 36.00 & 37.00 & 36.67 & 0.74 \\
Heterophil (\%) & 60.00 & 59.00 & 58.00 & 56.33 & 57.33 & 0.97 \\
Lymphocyte (\%) & 1.33 & 1.00 & 0.00 & 0.66 & 0.66 & 0.14 \\
Monocyte (\%) & 2.67 & 3.33 & 3.00 & 3.33 & 3.33 & 0.22 \\
Basophil (\%) & 0.00 & 0.00 & 0.00 & 0.00 & 0.00 & 0.00 \\
Eosophil (\%) & &
\end{tabular}

abcd Means in the same column with different superscripts were significantly $(\mathrm{p}<0.05)$ different.

T1 $(0 \%$ replacement level), T2 (25\% replacement level), T3 (50\%replacement level), T4 (75\% replacement level), T5 (100\% replacement level)

Table 5: Serum metabolites of ducks fed fermented cassava root-leaf meal blend as maize equivalent

\begin{tabular}{lllllll}
\hline Parameters & T1 & T2 & T3 & T4 & T5 & SEM \\
\hline Total Protein $(\mathrm{g} / \mathrm{l})$ & $5.60^{\mathrm{a}}$ & $5.70^{\mathrm{a}}$ & $4.48^{\mathrm{b}}$ & $4.46^{\mathrm{b}}$ & $4.24^{\mathrm{b}}$ & 0.17 \\
Globulin $(\mathrm{g} / \mathrm{l})$ & $2.18^{\mathrm{bc}}$ & $3.11^{\mathrm{a}}$ & $2.50^{\mathrm{b}}$ & $1.96^{\mathrm{bc}}$ & $1.85^{\mathrm{c}}$ & 0.13 \\
Albumin $(\mathrm{g} / \mathrm{l})$ & $3.42^{\mathrm{a}}$ & $2.79^{\mathrm{b}}$ & $2.51^{\mathrm{b}}$ & $2.50^{\mathrm{b}}$ & $2.35^{\mathrm{bc}}$ & 0.13 \\
Uric acid $(\mathrm{mg} / \mathrm{dl})$ & $5.30^{\mathrm{a}}$ & $4.93^{\mathrm{ab}}$ & $4.69^{\mathrm{ab}}$ & $4.53^{\mathrm{ab}}$ & $4.27^{\mathrm{b}}$ & 0.13 \\
Creatinine $(\mathrm{mg} / \mathrm{dl})$ & $0.39^{\mathrm{c}}$ & $1.06^{\mathrm{a}}$ & $1.17^{\mathrm{a}}$ & $0.80^{\mathrm{b}}$ & $0.67^{\mathrm{b}}$ & 0.08 \\
Triglycerol $(\mathrm{mg} / \mathrm{dl})$ & $41.20^{\mathrm{b}}$ & $40.16^{\mathrm{a}}$ & $36.87^{\mathrm{ab}}$ & $35.13^{\mathrm{ab}}$ & $33.00^{\mathrm{b}}$ & 1.06 \\
Cholesterol $(\mathrm{g} / \mathrm{l})$ & $91.70^{\mathrm{a}}$ & $89.83^{\mathrm{a}}$ & $83.77^{\mathrm{a}}$ & $60.50^{\mathrm{b}}$ & $56.70^{\mathrm{b}}$ & 4.21 \\
Aspartate transferase $(\mathrm{iu} / \mathrm{l})$ & $14.20^{\mathrm{b}}$ & $14.77^{\mathrm{b}}$ & $15.12^{\mathrm{b}}$ & $16.67^{\mathrm{b}}$ & $22.57^{\mathrm{a}}$ & 0.87 \\
Alanine transferaseT(iu/l) & $71.30^{\mathrm{a}}$ & $70.00^{\mathrm{a}}$ & $66.30^{\mathrm{b}}$ & $47.97^{\mathrm{c}}$ & $44.67^{\mathrm{d}}$ & 3.05 \\
\hline
\end{tabular}

abcd Means in the same column with different superscripts were significantly $(\mathrm{p}<0.05)$ different.

T1 ( $0 \%$ replacement level), T2 (25\% replacement level), T3 (50\%replacement level), T4 (75\% replacement level), T5

(100\% replacement level). 


\section{Olayemi, Rabiu, Oso, Akapo and Bamgbose}

\section{Result and discussion}

The proximate composition of fermented cassava root- leaf meal as shown in Table 1. The fermented cassava root-leaf meal used in this study contain $9.3 \%$ crude protein, $3.79 \%$ crude fibre, $2.05 \%$ ash, $3.14 \%$ ether extract and $51.91 \%$ nitrogen free extract. The result of the haematological parameters (Table 2) revealed that The $\mathrm{RBC}, \mathrm{Hb}, \mathrm{RBC}$ and $\mathrm{WBC}$ all showed reference values. However, WBC values recorded were higher than reference values for the species used in this study. The blood parameters are good indicators of physiological, pathological and nutritional status of an animal and changes in values have the potential of being used to elucidate the impact of nutritional factors. This is supported by previous work that $\mathrm{RBC}, \mathrm{Hb}$ and other parameters vary among bird species and are affected by diet contents (Odunsi et al., 1999; Kurtoglu et al., 2005). According to Peters et al., 2011), previous reports stated that Packed Cell Volume, haemoglobin and mean corpuscular haemoglobin are major indices for evaluating circulatory erythrocytes, and are significant in the diagnosis of anaemia and also serve as useful indices of the bone marrow capacity to produce red blood cells as in mammals (Awodi et al., 2005; Chineke et al., 2006). Furthermore, Chineke et al. (2006) posited that high Packed Cell Volume (PCV) reading indicated either an increase in number of Red Blood Cells (RBCs) or reduction in circulating plasma volume. Blood is a tool used in evaluating the clinical and nutritional status of an animal in feeding trial (Adeyemi et al., 2000). There was significant difference in PCV HB RBC and WBC across the treatment. The packed cell volume (PCV) values of duck fed varying levels of FCRLM were 26.50, 32.00, 38.00, 38.33 and $32.00 \%$ for diets T1, T2, T3, T4 and $\mathrm{T} 5$ respectively. Hematological parameters are a reflection of effects of dietary treatments on animals in terms of the amount of feed ingested and available for the animal to meet up with the physiological and biochemical requirements (Ewuola et al., 2004). The highest value of PCV (38.33\%) was observed in duck fed diet (T4) which was not statistically different from diet (T3) with the PCV value of $38.00 \%$. The PCV recorded in this study is in line with the reference value documented by Ola et al.; (2010) but lower than the value reported by Okeudo et al.; (2003) who reported the reference value of PCV to be $43.45 \%$ for Mallard duck which may be due to difference in plane of nutrition and environmental exposure. The values of hemoglobin concentration in this study falls within the range $14.92 \%$ reported for mallard duck (Okeudo et al., 2003). The hemoglobin value was found to have increased as the level of inclusion of FRCLM increases in the diet, the value of $\mathrm{Hb}$ observed in this study increases from 9.35 to 14.0 which suddenly decline at $100 \%$ FCRLM inclusion. The highest value for $\mathrm{Hb}$ was observed at diet (T4) followed by diet (T2) having $14.07 \%$ and $13.18 \%$. The RBC recorded highest at $2.67 \%$ for diet (T3) followed by diet (T4), the value obtained in this study is in agreement with authors (Doubek et al., 2003; Campbell et al., 2013) who reported the recommended value of RBC for ducks to be $2.0-3.4 \%$. The values observed for white blood cell varied across the treatment, the values vary $10.73-12.17$ with ducks on $\operatorname{diet}$ (T3) observed to record the highest value of $12.17 \%$ while the least $(10.73 \%)$ was recorded for birds fed $\mathrm{T} 1$.

Table 3, showed that FCRLM at 50\% inclusion on serum metabolites like protein, globulin, albumin, uric acid, creatinine, triglyceride, cholesterol, AST and ALT significantly affected the values. A slight decrease was observed in protein, globulin, albumin, uric acid values with increase in 
the inclusion of test ingredient. The observed decrease in cholesterol level with increase in the FCRLM inclusion could be linked to bio active compounds like flavonoid, tannins and saponins present in cassava leaves which prevents LDL oxidation and decreases cholesterol and triglycerides (Sallappan and Akoh, 2002). Also saponin is able to lower biosynthesis of exogenous cholesterol by tying up bile salts and cholesterol in intestine which reduces cholesterol in the blood (Oyewole and Akingbala, 2011).

\section{Conclusion}

Based on the findings of this study, it can be concluded based on findings that cassava root when fermented with cassava leaves (at $300 \mathrm{~g} / \mathrm{kg}$ leaf- root) can successfully replace maize up to $50 \%$ and could enhance better health status of ducks. Also, its inclusion in diets of ducks will not have any negative effect on physiological, pathological and nutritional status of ducks. It is recommended that nutritive value of cassava can be improved through fermentation of cassava root with the leaves.

\section{References}

A. O. A. C., 2002. Association of Official Analytical Chemists, Official Methods of Analysis of AOAC International, 17th ed, Association of Official Analytical Chemists, Washington.

Adenkola, A.Y., Ayo, A.Y., Sackey, A. K. B. and Adelaiye, A.B. 2008. Haematological changes in pigs administered with ascorbic acid and transported by road for four hours during the harmattan season. Proceedings of 42nd Annual Conference of the Agricultural Society of Nigeria, 659-663

Adenkola, A. Y. and Dunotoye, L. A. 2004. Haematological study during pre- partum periods in brown Savanna does in Zaria, Nigeria. Proceeding of the 38th Annual Conference of the Agricultural Society of Nigeria, 538-540

Aderemi, F. A. 2004. Effects of replacement of wheat bran with cassava root sieviate supplemented or unsupplemented with enzyme on the haematology and serum biochemistry of pullet chicks. Tropical Journal Animal Science,7: 147-153.

Amakiri, A. O., Owen, O. J and Jack, D. O. 2009. Effects of refined petroleum product (kerosene) flame and fumes on haematological characteristics of broiler chickens. Proceedings of the 34th Annual Conference of the Nigeria Society for Animal Production, 41-44.

Aro, S. O. 2008. Improvement in the nutritive quality of cassava and its by-products through microbial fermentation. African Journal of Biotechnology, 7(25).

Awodi, S., Ayo, J. O., Atodo, A. D. and Dzende, T. 2005 . S o m e haematological parameters and the erythrocyte osomotic fragility in the $1 \mathrm{a} \mathrm{u} \mathrm{g} \mathrm{h} \mathrm{i} \mathrm{n} \mathrm{g} \mathrm{d} \mathrm{o} \mathrm{v} \mathrm{e}$ (Streptopellasenegalensis) and the vi 11 a g e w e a n e r bi r d (Ploceuscucullatus) Proceedings of the 10th Annual Conference of Animal Science Association of Nigeria.384-387.

Bamishaiye, E. I., Muhammad, N.O and Bamishaiye, O. M. 2010 . Haematological parameters of albino rats fed on tiger nuts (Cyperussesculentus) tuber oil meat based diet. The Internet Journal of Nutrition and Wellness, 10(1).

Bawala, T. O., Akpan, U., Ogunnowo, A. O., Fasae, O. A. and Sogunle, O. M. 2007. Influence of $\mathrm{Mg}$ 
supplementation on the haematological indices of young West African Dwarf (WAD) goats. Proceeding of the 32nd Annual Conference of Nigeria Society for Animal Production, 76-78.

Campbell, T. W., Smith, S. A. and Zimmerman, K. L. 2010 . Hematology of waterfowl and raptors. In: Weiss, D. J, Wardrop, K. J: Schalm's Veterinary Hematology. Wiley-Blackwell, Arnes, pp 977-986

Chineke, C. A., Ologun, A. G. and Ikeobi, C. O. N. 2006. Haematological parameters in rabbit breeds and crosses in humid tropics. Pakistan Journal of Biological Sciences, 9: 2102-

2106.

Coles, E. H. 1974. Veterinary clinical pathology. 4th ed. E. H. Coles, W. B. Saunders Company, Philadelphia, USA.

Doyle, D. (2006). William Hewson (173974). The father of haematology. British Journal of Haematology, 133:375-381.

Doubek J., Bouda J., Doubek M., Fürll M., Knotková Z., Pejřilová S., Pravda D., Scheer P， Svobodová Z, Vodička $R$ 2003: Veterinary Haematology (in Czech). Noviko, Brno, 464

D'Mello, J., Acamovic, T. and Walker, A. G. 1987. Evaluation of leucaena leaf meal for broiler growth and pigmentation. Journal of Tropical Agriculture. (Trinidad), 64: 33-35.

Eruvbetine D., Tajudeen I. D., Adeosun A. T. and Olojede A. A. 2003. Cassava (manihot esculenta). Leaf and tuber concentrate in diets for broiler chickens. Bioresource Technology, 86: 277-281.

Google Earth, 2011. http/www.google, earth retrieved on $01 / 02 / 2019$
Iheukwumere, F.C. and Herbert, U. 2012. Physiological responses of broiler chickens to quantitative water restrictions: Haematology and serum biochemistry. Journal of Poultry Science, 117-119.

Kurtoglu, F., Kurtoglu, V., Celik, I., Kececi, I. and Nizamlioglu, $M$. 2005. Effect of dietary boron supplementation on some biochemical parameters peripheral blood lymphocytes, splenic plasma cells and bone characteristics of broiler chicks given diets with adequate or inadequate cholecalferol (Vitamin D) content. British Poultry Science. 46:87-96.

NRC (National Research Council) 1994. Nutrient requirements of poultry. (9th ed.) National Academy Press, Washington, DC.

Oboh, G. and Akindahunsi, A. A. 2003. Biochemical changes in cassava products (flour \& gari) subjected to Saccharomyces cerevisae solid media fermentation. Food chemistry, 82(4), 599-602.

Odunsi, A. A., Onifade, A. A. and Babatunde, G. M. 1999. Response of broiler chicks to virginmycin and dietary protein concentration in the humid tropics. Archivous Zootechinical.48(183):317-325.

Okeudo, N. J., Okoli, I. C. and Igwe, G. O. F. 2003. Hematological characteristics of ducks (Cairina moschata) of southeastern Nigeria. TROPICULTURA, 2003, 21 (2) 61-65

Ola, S. I., Oregun, M. A. and Adeloye, A. O. 2000. Hematological values of the local muskovy ducks of Nigeria, in: The proceedings of the XXI World's Poultry Congress, August 20-24 2000. Montreal, Canada. (CD ROM).

Owosibo, A. O, Longe, O. G. 2007. Response of pullet chicks to graded 
levels of dry extruded fat soybean. Proceedings of the 41st Annual Conference of the Agricultural Society of Nigeria, 345.

Oyewole, O.I and Akingbala, P. F. 2011. Phytochemical analysis and hypolipidemic properties of Jatropha tajorensis leaf extract. European Journal of Medicinal Plants, (1). 180-185.

Panigrahi, S. A. 1996. Review of the potential for using cassava root meal in poultry diets. Tropical tuber crops: problems, prospects and future strategies. Pages: 416-428.

SAS Institute, Inc. SAS/STAT(R) 2000. User's Guide, Version 9, Cary, NC: SAS Institute,
Tewe, O. O. and Iyayi, E. A. 1989. Cyanogenic glycosides, in: CHEEKE, P.R. (Ed) Toxicant of plant origin, Vol. II, Glycosides, p. 43-60 (CRS Press).

Schalm, O. W., Jain, N. C. and Carol, E. 1975. Veterinary haematology $3 \mathrm{rd}$ edition. Lea and Febiger, Philadelphia, USA.160-210.

Sellappan, S and Akoh, C.C. 2002. Flavonoids amd antioxidant capacity of Georgia-grown vidalia onions. Journal of Agriculture and Food Chemistry. 50: 5338-5342.

Yeoh, H. and Yruong, V. 1993. Quantitative analysis of linamarin in cassava using a $B$ glucosidase electrode. Food Chemistry 47: 295298.

Received: $10^{\text {th }}$ November, 2019 Accepted: $22^{\text {nd }}$ February, 2020 